\title{
The Effects of Regulatory Focus on Channel Choice and Recommendation:
}

Analyzing Multichannel Shopper Behavior

\section{制御焦点がチャネル選択・推奨に及ぼす影響 \\ ーマルチ・チャネルショッパー行動の分析 —}

\author{
Ryuta Ishii ${ }^{* 1}$, Mai Kikumori ${ }^{* 2}$ \\ 慶應義塾大学大学院 後期博士課程 \\ 石井 隆太 \\ 立命館大学 経営学部 准教授 \\ 菊盛 真衣

\footnotetext{
${ }^{* 1}$ Graduate School of Business and Commerce, Keio University, ryuta.ishii@keio.jp

${ }^{* 2}$ Associate Professor, Faculty of Business and Administration, Ritsumeikan University, kikumori@fc.ritsumei.ac.jp
}

\begin{abstract}
Today, the number of multichannel shoppers, consumers who shop at both physical and online stores, has increased. Previous research has implied that multichannel shoppers' regulatory focus may affect the store choice. However, there remain two limitations: (1) prior studies have not considered online shopping experience, which influences perceived channel attributes; and (2) they have failed to examine consumers' recommendation behaviors. To address these limitations, we investigate the effects of multichannel shoppers' regulatory focus on the store choice and recommendation, and the moderating effects of online shopping experience on the causal relationships. A survey using the scenario method was conducted and a dataset was collected from 241 participants. The results of regression analyses showed that a prevention focus has negative impacts on online store (vs. physical store) choice and recommendation. In contrast, when online shopping experience is high, a promotion focus has positive impacts on the online store (vs. physical store) choice and recommendation. By providing these findings, this study contributes to advancing research on channel choice, word-of-mouth, and regulatory focus theory.
\end{abstract}

Keyword : Multichannel strategy, Shopping behavior, Word-of-mouth, Regulatory focus theory, Online purchase experience

要約 : 今日, 実店舗とオンライン店舗の両方で買物する消費者, すなわち, マルチ·チャネルショッパーが増加している。既存 研究は，マルチ·チャネルショッパーの制御焦点が店舗選択に影響を及ぼすということを示唆してきた。しかし，(1）チャネル 属性の知覚水準に影響を及ぼしうるオンライン購買経験を考慮に入れていない点, および, (2) 消費者の店舗推奨行動を検討し ていない点において問題が残されている。これらの問題に対応するために, 本論は, マルチ・チャネルショッパーの制御焦点が 店舗選択・推奨に及ぼす影響, および，その影響に対するオンライン購買経験の調整効果を検討する。シナリオ法を用いた調査 を実施し，241 名の参加者からデータを収集した。回帰分析の結果，予防焦点は，オンライン店舗(対実店舗)の選択および推奨 行動に負の影響を及ぼす一方, 消費者のオンライン購買経験が多い場合, 促進焦点は, オンライン店舗(対実店舗)の選択および 推奨行動に正の影響を及ぼすということが見出された。こうした知見を提示することで, 本論は, 消費者のチャネル選択に関す る研究, クチコミに関する研究，および，制御焦点理論に関する研究の進展に貢献を成すだろう。

キーワード : マルチ·チャネル戦略, 買物行動, クチコミ, 制御焦点理論, オンライン購買経験

Information : Received 15 June 2018; Accepted 16 July 2018 


\section{I. はじめに}

複数の販売チャネルを通じて製品を提供することは, 小売業者にとって今や一般的な戦略になっている（Van Bruggen, Antia, Jap, Reinartz, \& Pallas, 2010）。今日の小 売業者は, 実店舗やカタログなどの従来の販売チャネル に加えて, 直営サイトやモバイルアプリなどのオンライ ンチャネルを設置している。消費者側に目を向けてみる と, 数多くの消費者は, こうした複数の販売チャネルを 利用して買物を行っている (Neslin et al., 2006; Verhoef, Nestlin, \& Vroomen, 2007)。我が国でも, 特にミレニアル 世代と呼ばれる 10２0 代の消費者は，1日あたり平均で 3 時間以上をインターネット通信を目的とするスマート フォンの利用に費やしており，製品の購買を実店舗だけ ではなく，オンラインチャネルでも積極的に行う様子が 伺える（Ministry of Internal Affairs and Communications, 2017,p. 11)。このように複数の販売チャネルを利用して 買物を行う消費者は, マルチ・チャネルショッパーと呼ば れている（Kumar \& Venkatesan, 2005; Kushwaha \& Shankar, 2013)。インターネットやスマートフォンの普及 率・使用率はますます高まっており，オンラインショッ ピング利用経験者も増加していることに鑑みると, マル チ・チャネルショッパーの数は, 今後さらに増加していく と予想される。それゆえ, 今日の小売業者にとって極め て重要な課題として, マルチ・チャネルショッパーの心理 や行動に関する理解を深めるということが挙げられるだ ろう。

そうした試みの一つとして, マーケティング論ないし 消費者行動論においては, マルチ・チャネルショッパーが 如何なる時にオンライン店舗を選択して, 如何なる時に 実店舗を選択するのかというチャネル選択問題が検討さ れてきた。マルチ・チャネルショッパーのチャネル選択を 規定する要因として, チャネル要因（e.g., Huang \& Oppewal, 2006; Montoya-Weiss, Voss, \& Grewal, 2003; Verhoef et al., 2007; Wang, Lin, Tai, \& Fan, 2016; Yu, Niehm, \& Russell, 2011)，製品要因（e.g., Elliot \& Fowell, 2000), 状況要因 (e.g., Chocarro, Cortiñas, \& Villanueva, 2013; Gehrt \& Yan, 2004; Hand, Dall'Olmo Riley, Harris,
Singh, \& Rettie, 2009; Nicholson, Clarke, \& Blakemore, 2002), および, 個人要因 (e.g., Cervellon, Sylvie, \& Ngobo, 2015; Dai, Forsythe, \& Kwon, 2014）が取り上げられてき た。その中でも, 個人要因に着目した研究は, 顧客セグ メンテーション方法に関する含意を提供しうる点におい て実務的示唆が豊富であるため, 今後ますます取り組む 必要があると指摘されている（Cervellon et al., 2015）。し たがって，個人要因，特に消費者の制御焦点が，マルチ. チャネルショッパーのチャネル選択を規定する要因にな りうると示唆した Kushwaha and Shankar（2013）は注目 に值するだろう。彼らは, 促進焦点の消費者は, 不確実 性や新規性の高いオンライン店舗やマルチ・チャネルを好 み, そこで快楽的ないし高リスクの製品を購買する一方, 予防焦点の消費者は, 馴染み深くて安心感の高い実店舗 を好み，そこで実用的ないし低リスクの製品を購買する という興味深い主張を展開している。

しかしながら, Kushwaha and Shankar（2013）は, 全 ての消費者が実店舗とオンライン店舗のそれぞれに対し て同一水準のチャネル属性を知覚するということを, 暗 黙裡のうちに仮定してしまっている。消費者のチャネル 選択に関する既存研究においては, オンライン購買経験 の多寊が, 実店舗やオンライン店舗が有するチャネル属 性の知覚水準に大きな影響を及ぼすということが見出さ れている (e.g., Dai et al., 2014; Yang, 2012)。具体的には, オンライン購買経験が多い消費者は, オンライン店舗で 購買するリスクを低く知覚する一方, そこで購買する快 楽感を高く知覚するという。オンライン購買経験によっ て, チャネル属性の知覚水準が変化するということを考 慮に入れると, 制御焦点がチャネル選択に及ぼす影響の 大小は, オンライン購買経験の多寡に左右されると考え られるだろう。

また, 大半の既存研究は, マルチ・チャネルショッパー のチャネル選択行動に焦点を合わせてきたが，マルチ・ チャネルショッパーが選択したチャネルについて他者に 推奖するのか否かという研究課題は，未探究のまま残さ れている。他者への推奨やクチコミの発信は, 製品や店 舗の売上に極めて大きな影響を及ぼすため，そうしたク チコミの発生メカニズムを検討する研究が盛んに行われ ている (e.g., Godes et al., 2005; Ono \& Kikumori, 2017) 
ということを考慮に入れると，チャネル選択行動だけで はなく, チャネル推奨行動もまた研究対象に設定する必 要があろう。

既存研究が残した問題点に対応するために, 本論は, マルチ・チャネルショッパーの制御焦点がオンライン店舗 (対実店舗)の選択·推奨行動に及ぼす影響，および，その 影響に対するオンライン購買経験の調整効果を検討する ことを試みる。本論の取り組みは, 消費者のチャネル選 択に関する研究，クチコミに関する研究，および，制御 焦点理論に関する研究の進展に一定の貢献を成すだろう。

\section{II. 既存研究レビュー}

\section{1．消費者のチャネル選択に関する既存研究}

マーケティング論において，チャネル選択に関する研 究は，企業のチャネル選択に関する研究群，すなわち， 企業が自社製品を流通させるために如何なるチャネルを 選択するのかという問題を取り扱った研究群（e.g., Anderson, 1985; Weiss, Anderson, \& MacInnis, 1999) と, 消費者のチャネル選択に関する研究群，すなわち，消費 者が製品を購買するために如何なるチャネルを選択する のかという問題を取り扱った研究群（e.g., Bell \& Lattin, 1998; Oppewal, Timmermans, \& Louviere, 1997）に大別さ れる。両者の研究群に共通する近年の傾向として, マル チ・チャネルに焦点を合わせた研究が盛んに展開されてい るということが挙げられる。

一方で，企業のチャネル選択に関する研究は，どのよ うな時に, 企業が複数種類のチャネルを選択するのかと いうテーマを取り扱ってきた（e.g., Ishii, 2018; Jindal, Reinartz, Krafft, \& Hoyer, 2007; Sa Vinhas \& Anderson, 2005)。換言すると, これらの研究は, 企業のマルチ. チャネル化を規定する要因を検討してきた。例えば，Sa Vinhas and Anderson (2005) は, 直接チャネルと間接チャ ネルの間でコンフリクトが生じないような時には, B2B メーカーは双方のチャネルを選択すると主張した。また, Jindal et al.（2007）は，企業の顧客志向や標的顧客の専 門性が高い時には，B2Cメーカーは多様なチャネルを選 択するということを見出した。
他方で, 消費者のチャネル選択に関する研究は, 企業 によって設置された複数種類のチャネルのうち，どのよ うな時に, 消費者はそれらを組み合わせて選択するのか というテーマ (e.g., Gensler, Verhoef, \& Böhm, 2012; Oppewal, Tojib, \& Louvieris, 2013）や, どのような時に, それらのチャネルのうちの特定のチャネルを選択するの かというテーマ（e.g., Neslin et al., 2006）を取り扱って きた。その中でも, オンライン店舗と実店舗のうち, 消 費者は, どのような時にいずれを選択するのかというテー マは, 現実世界においてマルチ・チャネルショッパーが頻 繁に直面する意思決定問題であるため, 最も重要な研究 課題の一つとして位置づけられてきた（Chocarro et al., 2013; Monsuwé, Dellaert, \& De Ruyter, 2004)。

この研究課題を取り扱った既存研究は, オンライン店 舗(対実店舗)の選択を規定する要因を探究してきた。こ れまでに見出されてきた規定要因は, 主として次の 4 つ のカテゴリーに分類しうる。第一は, チャネル要因であ る。チャネル要因に着目した既存研究は, 購買を行うチャ ネルの属性水準が，チャネル選択に及ぼす影響を探究し てきた (e.g., Huang \& Oppewal, 2006; Montoya-Weiss et al., 2003; Verhoef et al., 2007; Wang et al., 2016; Yu et al., 2011）。例えば, Huang and Oppewal（2006）は，オンラ イン店舗(対実店舗)の選択を規定する要因として, 店舗 での購買に伴う金銭的・心理的費用, 店舗での購買過程で 得られる快楽感, 店舗での購買に伴うリスクに着目した。 彼らは, 生鮮食品についてシナリオ実験を行ってデータ を収集し，分析を行った結果，オンライン店舗の選択に 対して, 店舗での購買過程で得られる快楽感は正の影響 を及ぼす一方, 店舗での購買に伴う心理的費用とリスク は負の影響を及ぼすということを見出した。

第二は，製品要因である。製品要因に着目した既存研 究は, 購買対象製品の特性が, チャネル選択に及ぼす影 響を探究してきた（e.g., Elliot \& Fowell, 2000）。例えば, Elliot and Fowell（2000）は, 35 人の学生から 107 のオン ライン店舗における買物データを収集して，オンライン 店舗で購買されやすい製品の特性を探索的に識別した。 その結果, 書籍や音楽 $\mathrm{CD}$ のように, 規格品で, 消費者 が精通している製品は，実店舗ではなくオンライン店舗 で購買されやすい一方，ボディローションや衣服のよう 
に, 非規格品で，店員によるサービスが必要な製品は, オンライン店舗ではなく実店舗で購買されやすいという ことを見出した。

第三は, 状況要因である。状況要因に着目した既存研 究は, 消費者を取り巻く時間や場所といった環境が, チャ ネル選択に及ほす影響を探究してきた（e.g., Chocarro et al., 2013; Gehrt \& Yan, 2004; Hand et al., 2009; Nicholson et al., 2002）。例えば，Chocarro et al.（2013）は，3つの 状況要因, すなわち, 実店舗までの距離のような物理的 要因, 購買までの猶予の無さのような時間的要因, およ び，他者の存在のような社会的要因が，オンライン店舖 (対実店舗)の選択に及ぼす影響を探究した。彼らは, 多 様なカテゴリーの製品についてシナリオ実験を行って データを収集し，分析を行った結果，物理的要因と時間 的要因が，オンライン店舗の選択に正の影響を及ぼすと いうことを見出した。

第四は，個人要因である。個人要因に着目した既存研 究は, 知識・経験・志向といった個々の消費者が有する 特性が,チャネル選択に及ぼす影響を探究してきた（e.g., Cervellon et al., 2015; Dai et al., 2014)。例えば，Dai et al. （2014）は, オンライン購買経験がオンライン店舗(対実 店舗)の選択に及ぼす影響を探究した。彼らは, デニム ジャケットと MP3 ファイルに関する大規模なオンライ ン調查を行ってデータを収集し，分析を行った結果，才 ンライン購買経験が，製品，決済情報，および，個人情 報に関する知覚リスクを低減させることを通じて, オン ライン店舗の選択に正の影響を及ぼすということを見出 した。

以上のように，既存研究は，オンライン店舗と実店舗 の選択に関する数々の規定要因を検討してきた。 Cervellon et al.（2015）は，大半の既存研究は，第一の要 因であるチャネル属性に着目しており，第四の要因であ る個人要因に着目した研究は希少であると指摘してい る。彼らによると，オンライン店舗や実店舗の選択に影 響を及ほす個人要因を同定することは，マーケティング 戦略に対する示唆を与える上で非常に重要な試みである という。なぜなら, 個人要因は, 企業が顧客セグメンテー ションを行うための有用な基準になりうるからである (Montoya-Weiss et al., 2003)。特に近年では, デモグラ
フィック要因ではなく, 消費者の心理的要因によって, セグメンテーションを実施することが有効であると示唆 されている (Cervellon et al., 2015)。そうした個人要因の 一つとして, 消費者の制御焦点が挙げられるだろう。次 節においては，制御焦点理論に依拠して，消費者の制御 焦点と買物行動の関係を検討した研究を概観したい。

\section{2. 制御焦点理論に関する研究}

制御焦点理論 (Higgins, 1997, 1998) は, 人間の動機づ けを制御する様式として, 促進焦点と予防焦点の 2 種類 の制御焦点を識別し，それらが人間の感情・思考・行動 に異なる影響を及ぼすと主張する。この理論によると， 促進焦点の個人は，達成・願望・熱望に注目しているた め, 肯定的な結果の有無からの影響を受けやすい一方, 予防焦点の個人は，安全・責任・義務に注目しているた め，否定的な結果の有無からの影響を受けやすいという (Higgins, 1997)。Higgins（1998）は，個人の促進焦点や 予防焦点の強弱は, 幼少期に面倒を見てくれた人との関 わり方によって異なると述べている。彼によると, 偉業 を達成したり願望を叶えたりすることを強調するような 向上的様式 (bolster mode) で関わると, 促進焦点が強化 される一方, 危険に注意したり自身の振る舞いに気を付 けたりすることを強調するような堅実的様式（prudent mode）で関わると，予防焦点が強化されるという。こう して形成された促進焦点や予防焦点の強弱は, 個人の意 思決定に影響を及ぼし, 自身の制御焦点に適合した意思 決定を行えれば，その状態を心地よく感じるため，その 意思決定を高く評価する (Avnet \& Higgins, 2006)。

制御焦点の概念を取り扱う際には, 次の 2 点に注意す るべきだろう。1点目は, 促進焦点と予防焦点は, 別次 元の概念であるということである。Higgins（1998）が, 「一人の個人について, 強い促進焦点が獲得されること も, 強い予防焦点が獲得されることも，あるいは，それ らの両方が獲得されることもある」(p. 16) と述べている ことから明らかなように, 促進焦点と予防焦点は, 制御 焦点という一次元で捉えられる概念ではなく，それぞれ は，独立した概念である（Haws, Dholakia, \& Bearden, 2010）。実際, 既存の実証研究は, 個人の促進焦点と予 防焦点を別々に測定しており，また，両者の相関は極め 
て小さく, なおかつ, 統計的に非有意であるということ を見出している (e.g., Gorman et al., 2012; Summerville \& Roese, 2008)。2 点目は, 人間の制御焦点は, 慢性的な特 性である一方, 一時的な状況でもあるということである。 すなわち, 個人ごとに, 促進焦点や予防焦点の強弱は異 なりうるし, 同一の個人でも, 状況によってそれらの強 弱は異なりうる。したがって, 実証分析に際して, 制御 焦点を個人要因として捉えた上で，その実態を測定する 研究もあれば（e.g., Avnet \& Higgins, 2006)，それを状況 要因として捉えた上で, 個人に刺激を与えて操作する研 究もある (e.g., Wang \& Lee, 2006)。

制御焦点は, 消費者の動機要因の一つとして見なすこ とができ, それは, 消費者が追い求める目標, 達成しょ うとするニーズ，あるいは，形成する思考に多大な影響 を及ぼす (Pham \& Higgins, 2005)。それゆえ， 2000 年以 降, マーケティング論や消費者行動論の研究者たちは, 制御焦点理論を, 広告, セールスプロモーション, ある いは，買物行動といった多様な文脈で援用してきた（cf. Ishii, 2009)。制御焦点理論を買物行動の文脈に援用した 研究として, Arnold and Reynolds (2009), Kushwaha and Shankar（2013)，および, Das（2016）が挙げられる。 これらのうち, Arnold and Reynolds (2009), および, Das（2016）は, 特定の単一種類の店舗における消費者 の買物行動を研究対象に設定しているため, シングル. チャネルに関する研究に位置付けられる一方, Kushwaha and Shankar（2013）は，複数種類の店舗における消費者 の買物行動を考慮に入れているため, マルチ・チャネルに 関する研究に位置付けられるだろう。

Arnold and Reynolds（2009）は, 消費者の制御焦点が, 消費者の気分 (ムード) や買物価值に及ぼす影響を探究 した。彼らは, オンライン・サーベイを行って消費者デー 夕を収集し, 分析を行った結果, 促進焦点の消費者は, 自身の気分を向上させ，買物の快楽的価值を高く知覚す る一方, 予防焦点の消費者は, 自身の気分を正確に把握 して，買物の実用的価值を高く知覚するということを見 出した。加えて, 消費者は, 快楽的価值や実用的価值を 高く知覚すると, 当該店舗に関する正のクチコミを発信 する傾向にあるということを見出した。

Das（2016）は，消費者の制御焦点が，買物時の多様
な行動, すなわち, 買物価值の知覚, 衝動購買, 再購買, 正のクチコミの発信，および，買物時間に及ぼす影響を 探究した。ショッピング・モールにおいて店頭出口調査を 行って消費者デー夕を収集し, 分析を行った結果, 促進 焦点の消費者は, 予防焦点の消費者に比して, 買物の快 楽的価值を高く知覚し, 衝動購買を行い, 再購買や正の クチコミの発信を行わず，買物時間が短い傾向にあると いうことを見出した。

制御焦点理論を, マルチ・チャネルに関する研究に援用 したのが, Kushwaha and Shankar（2013）である。彼ら は, マルチ・チャネルショッパーが金銭的価值に及ぼす影 響を，製品カテゴリーが如何に調整するのかということ を検討するのに際して，消費者の制御焦点に着目した。 彼らによると, 制御焦点, 店舗種類, および, 製品カテ ゴリーには, 適合性が存在するという。具体的には, 促 進焦点の消費者は, 革新的で不確実性の高いオンライン 店舗やマルチ・チャネルでの購買, および, 快楽的ないし 高リスクの製品カテゴリーでの購買に適合感を抱くとい う。他方, 予防焦点の消費者は, 馴染み深くて安心感の 高い実店舗での購買, および, 実用的ないし低リスクの 製品カテゴリーでの購買に適合感を抱くという。彼らの 研究は, 購買店舗の種類と購買製品カテゴリーの交互効 果を検討するのに際して, 制御焦点理論が有用であると いうことを示した点において, 制御焦点理論に関する研 究に大きな貢献を成したと評価することができる。

\section{3. 問題の所在}

Kushwaha and Shankar（2013）は, 制御焦点が店舗選 択に及ぼす影響を明示的に検討したわけではないが, 彼 らの主張は, 制御焦点と店舗選択の関係について, 次の ように示唆していると考えられるだろう。すなわち, 促 進焦点の消費者は, 不確実性や新規性の高いオンライン 店舗を選択する一方，予防焦点の消費者は，馴染み深さ や安心感の高い実店舗を選択するということである。し かしながら, 彼らは, オンライン購買経験を考虑に入れ ていないという問題を抱えている。既存研究において見 出されてきたように, オンライン購買経験は, チャネル 属性の知覚水準に多大な影響を及ぼす。すなわち，オン ライン購買経験の多い消費者は, オンライン店舗のリス 
クを低く知覚する一方，そこで購買する快楽感を高く知 覚する (e.g., Dai et al., 2014; Yang, 2012)。したがって, 制御焦点がチャネル選択に及ぼす影響の大小は，オンラ イン購買経験の多萓に依存すると考えられるだろう。加 えて，Kushwaha and Shankar（2013）を含む大半の既存 研究は, マルチ・チャネルショッパーの店舗選択行動に焦 点を合わせてきたが，マルチ・チャネルショッパーの店舖 推奨行動には焦点を合わせてこなかった。しかしながら， 他者への推奨やクチコミの発信は，製品や店舗の売上に 極めて大きな影響を及ぼすため，そうしたクチコミの発 生メカニズムを検討する研究が盛んに行われている (e.g., Godes et al., 2005; Ono \& Kikumori, 2017）ということを 考慮に入れると，チャネルの選択だけではなく，チャネ ルの推奨もまた研究対象に設定する必要があろう。これ らの問題を踏まえて, 制御焦点が店舗選択・推奖に如何 なる影響を及ぼすのかということ，および，その影響を オンライン購買経験が如何に調整するのかということを 検討することが急務だろう。

\section{III. 仮説提唱}

\section{1. 促進焦点が店舗選択・推奨に及ぼす影響に関する仮説}

制御焦点理論によると，促進焦点の個人は，達成・願 望・熱望に注目しているため, 肯定的な結果の有無から の影響を受けやすいという（Higgins, 1997, 1998）。これ を踏まえると，促進焦点の消費者は，購買店舗を選択す るのに際して, ある店舗での購買によって得られる便益 に注目するだろう。消費者のチャネル選択に関する数多 くの既存研究 (Huang \& Oppewal, 2006; Verhoef et al., 2007; Wang et al., 2016; Yu et al., 2011）が主張してきたよ うに，消費者の店舗選択を駆動する便益は，店舗で購買 する快楽感である。快楽感とは, 買物の過程で得られる 喜びと定義される（Beatty＆ Ferrell, 1998）。促進焦点の 消費者は，購買店舗の選択に際して，ある店舗で購買す る快楽感を高いと知覚すれば，当該店舗を選択するだろ う。また，ある店舗を選択する意図が高い消費者は，当 該店舗での購買を他者に勧める傾向にある（Hahn \& Kim, 2009）。それゅえ，促進焦点の消費者は，快楽感を高い
と知覚した店舗での購買を他者に推奨するだろう。

オンライン店舗と実店舗のうち, どちらの店舗で購買 する快楽感を，消費者が高いと知覚するかは，オンライ ン購買経験の多㙞によって左右されるだろう。一方で, オンライン購買経験が多い消費者は, オンライン店舗で 頻繁に購買を行っているため, オンライン店舗での購買 を，快適で楽しいと知覚する（e.g., Pappas, Pateli, Giannakos, \& Chrissikopoulos, 2014; Yang, 2012)。それゆ え, オンライン購買経験が多い場合, 促進焦点の消費者 は, 購買に際して, オンライン店舗を選択し，オンライ ン店舗での購買を他者に推奨するだろう。他方で，オン ライン購買経験の少ない消費者は，オンライン店舗での 購買経験がほとんど無いため, 実店舗での購買を, 快適 で楽しいと知覚する。それゆえ, オンライン購買経験が 少ない場合, 促進焦点の消費者は, 購買に際して, 実店 舖を選択し，実店舖での購買を他者に推奨するだうう。 以上より，次の仮説を提唱する。

仮説 1 オンライン購買経験が多い場合, 促進焦点は, (a) オンライン店舗(対実店舗)の選択に正の影響を 及ぼし，(b) オンライン店舗(対実店舗)の推奨に 正の影響を及ぼす。

仮説 2 オンライン購買経験が少ない場合, 促進焦点は, (a)オンライン店舗(対実店舗)の選択に負の影響を 及ぼし，(b) オンライン店舗(対実店舗)の推奨に 負の影響を及ぼす。

\section{2. 予防焦点が店舗選択・推奨に及ぼす影響に関する仮説}

制御焦点理論によると, 予防焦点の個人は, 安全・責 任・義務に注目しているため，否定的な結果の有無から の影響を受けやすいという（Higgins, 1997, 1998）。これ を踏まえると, 予防焦点の消費者は, 購買店舖の選択に 際して，店舗で購買するリスクに注目し，知覚リスクの 低い店舗を選択するだろうし，また，そうした店舗での 購買を他者に推奨するだろう。

オンライン購買経験の多寡にかかわらず，消費者は， オンライン店舗での購買の方が, 実店舗での購買に比し て、リスクを高く知覚するだろう。なぜなら，オンライ ン店舗で購買するのに際しては，実物を見て品質を判断 
することができないし，個人情報や決済情報が漏洩する 恐れがあるからである（Dai et al., 2014）。そのため，予 防焦点が強いほど，その消費者が実店舗を選択・推奨す る傾向は高いだろう。

しかしながら，オンライン購買経験が多い消費者は, オンライン購買経験が少ない消費者に比して, オンライ ンで頻繁に購買を行っているため, オンライン店舗で購 買することに対して，それほどリスクを高く感じないだ ろう。したがって，オンライン購買経験が多い場合，予 防焦点が強くても，その消費者が実店舗を選択・推奨す る傾向は，それほど高くはないだろう。以上より，次の 仮説を提唱する。

仮説 3 予防焦点は，（a）オンライン店舗(対実店舗)の選 択に負の影響を及ぼし，（b）オンライン店舗(対実 店舗)の推奨に負の影響を及ぼす。

仮説 4 オンライン購買経験は，予防焦点が (a) オンラ イン店舗(対実店舗)の選択に及ぼす負の影響を抑 制し，（b）オンライン店舗(対実店舗)の推奨に及 ぼす負の影響を抑制する。

\section{IV. 調查方法}

\section{1. データの収集}

前章において提唱された仮説を経験的にテストするた めに，消費者デー夕を収集して実証分析を行った。調査 回答者は，関西圈の大学生 241 名であった。回答者の性
別は, 男性が $62.3 \%$, 女性が $37.7 \%$ であり, 回答者の年 齢は, 20 歳〜 21 歳が $80.1 \%, 22$ 歳〜 23 歳が $17.3 \%, 24$ 歳〜26 歳が $2.6 \%$ であった。

消費者のチャネル選択に関する既存研究 (e.g., Chocarro et al., 2013; Huang \& Oppewal, 2006）の調査方法に準拠し て，本論はシナリオ法を採用した。チャネル選択という 意思決定について，シナリオ間で同一の状況を回答者に 提示することによって，製品要因や状況要因を統制する ことができる一方，重要な変数については，シナリオ間 で異なる状況を提示することによって操作することがで きる。かくして，図1に示されるように，回答者には， 海水浴のための衣類を購買するという仮想の状況を描写 したシナリオを読んでもらった。既存研究 (e.g., Chocarro et al., 2013; Hand et al., 2009）において特に重要視されて きた状況要因, すなわち, 物理的要因と時間的要因を統 制するために，2（実店舗までの距離：近い／遠い） $\times 2$ (時間制限：緩い／厳しい）の 4 つのシナリオを作成し た。なお，回答者には，これらのシナリオのうち 1 つの シナリオが無作為に割り当てられた。

\section{2. 測定方法}

本論において用いられた構成概念と質問項目は, 表 1 に示されるとおりであった。従属変数は，実店舗に比し てオンライン店舗を選択する意図, および, 実店舗に比 してオンライン店舗を推奨する意図である。これらの変 数を測定するために, 回答者には, 各自に割り当てられ たシナリオを読んでもらった後に, オンライン店舗選択 意図，実店舗選択意図，オンライン店舗推奨意図，およ

あなたは，3週間後［1週間後］に，海水浴に出掛ける予定があります。そこで，UV カット（紫外線を通さない）パーカー, Tシャツ, ハーフパンツなどの海用の衣類を 買いたいと思っています。今日は土曜日で，あなたは，自宅に友人を招き，お昼を食 べ，お喋りをして解散したところです。現在，時刻は，16時です。

さて，あなたは，今から，3週間後 [1週間後］に迫った海水浴用の衣類を買いに出 掛けるかどうかを迷っています。今日の夕飯は，19時に，自宅で家族と食べる予定な ので，19時には家にいなくてはなりません。自宅から，REGFOSという行きたいお店 までは，約30分 [1時間］かかります。ただ，REGFOSは，オンラインショップがあ るので，店頭に行かずに，スマホやパソコンで，検索・購入することもできます。家 にいれば，テレビを観たり，明日の授業レポートを進めたりすることもできそうです。 


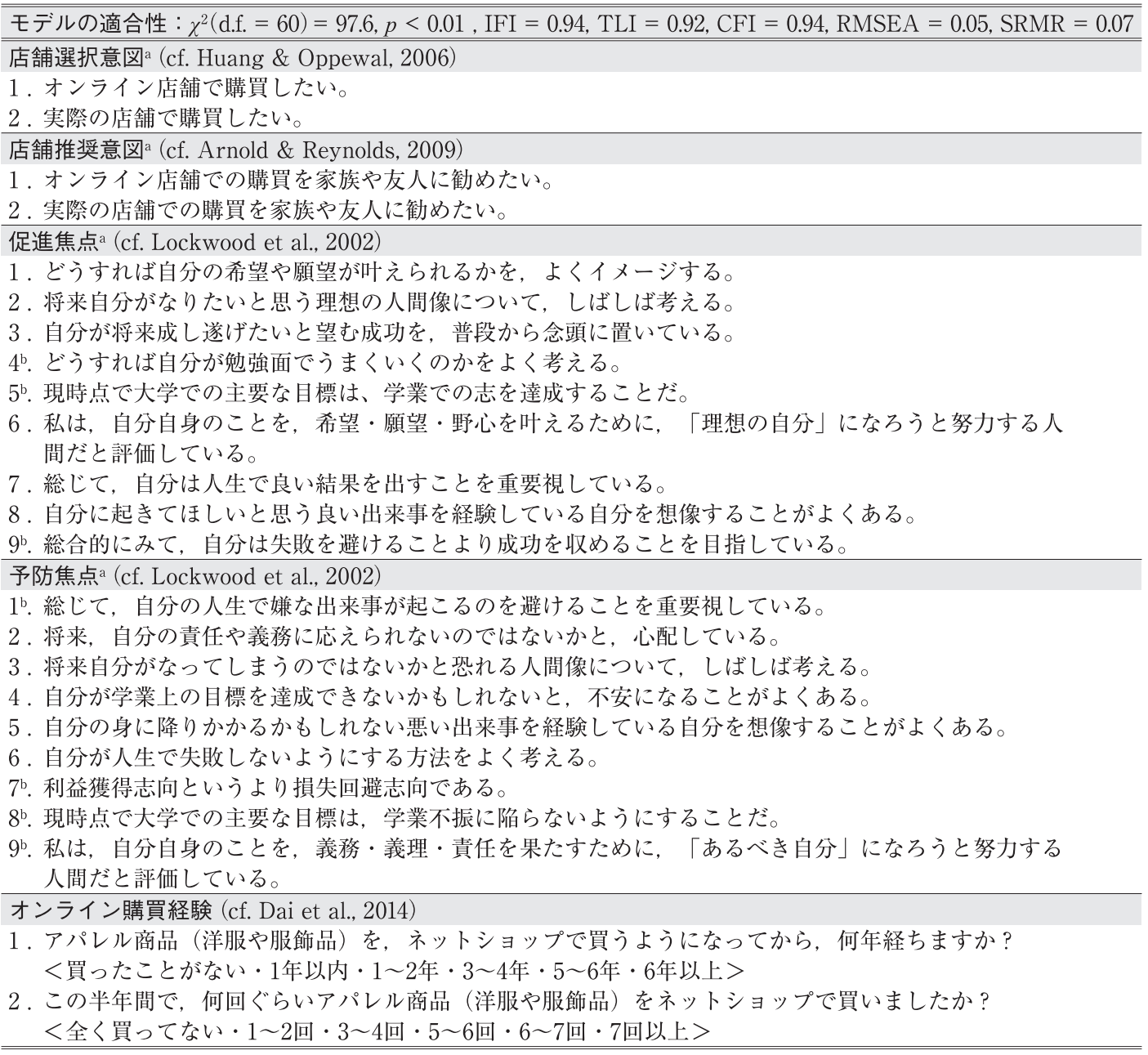

ただし， $a \cdots 7$ 点リカート尺度（1：全くそう思わない〜 7 : 非常にそう思う)。

b…分析に際して除外された質問項目。

び，実店舗推奨意図の 4 つの質問項目に回答してもらっ た。次に，実店舗に比してオンライン店舗を選択する意 図については，オンライン店舗選択意罒から実店舗選択 意図を減じた值を算出して用いた。同様に，実店舗に比 してオンライン店舗を推奨する意図については, オンラ イン店舗推奨意図から実店舗推奨意図を減じた值を算出 して用いた（cf. Huang \& Oppewal, 2006）。なお，店舗選 択意図については, Huang and Oppewal（2006）の質問項 目を，店舗推奨意図については，Arnold and Reynolds （2009）の質問項目を用いた。
独立変数は，制御焦点とオンライン購買経験である。 制御焦点については, 既存研究において最も頻繁に採用 されている Lockwood, Jordan, and Kunda（2002）の測定 尺度を用いた（cf. Gorman et al., 2012）。そのため, 促進 焦点と予防焦点を測定するために，それぞれ 9 つの質問 項目を設定した。これらのうち，促進焦点に関する 3 つ の質問項目，および，予防焦点に関する 4 つの質問項目 は，他の質問項目との相関が低かったため，分析に際し ては除外した。なお，促進焦点と予防焦点の相関係数は, $0.03(p>0.10)$ という值であり，促進焦点と予防焦点を 
一次元ではなく，二次元で捉えることが適しているとい うことが示唆された。こうした結果は, Lockwood et al. （2002）や Haws et al.（2010）の分析結果と整合的であ る。オンライン購買経験については, Dai et al. (2014) を参考に，2つの質問項目を用いた。

統制変数は, 実店舗までの距離, 時間制限, および, 性別の 3 つの変数である。具体的には, 実店舗までの距 離について，自宅から実店舗に行くまでにかかる時間が 1 時間というシナリオを読んだ場合には 1 ，その時間が 30 分というシナリオを読んだ場合には 0 とコード化し た。他方, 時間制限について, 海水浴に出掛ける予定日 が 1 週間後というシナリオを読んだ場合には 1,3 週間 後というシナリオを読んだ場合には 0 とコード化した。 また，性別については，回答者が女性であれば 1 ，男性 であれば 0 をとる女性ダミーを作成した。

Haws et al.（2010）の手続きに従って，概念の妥当性 をテストするために, 促進焦点, 予防焦点, および, 才 ンライン購買経験の測定尺度を用いて, 探索的因子分析, および，確認的因子分析を行った。探索的因子分析の結 果，明確な 3 因子構造が見出され，各質問項目の因子負 荷量は， 0.40 以上という充分に大きな值であった。ま た，確認的因子分析の結果，モデル全体の適合度は，満 足のいく值を示した $\left(\chi^{2}\right.$ (d.f. $\left.=60\right)=97.6, p<0.01, \mathrm{IFI}=0.94$, $\mathrm{TLI}=0.92, \mathrm{CFI}=0.94, \mathrm{RMSEA}=0.052, \mathrm{SRMR}=0.069)$ 。 $L$
たがって，概念の妥当性は，充分に高いと結論づけられ るだろう。

\section{V. 分析結果}

\section{1. 店舗選択に関する分析結果}

仮説 $\mathrm{a}$ 群, すなわち, 店舗選択に関する仮説 $1 \mathrm{a} \sim$ 仮説 4a をテストするために, オンライン店舗(対実店舗)選択 意図を従属変数に設定した回帰分析を行った。分析の結 果は, 表 2 に示されるとおりであった。Model $\mathrm{A}_{1}$ は, 統 制変数のみを組み込んだモデル, Model $\mathrm{A}_{2}$ は, 制御焦点 およびオンライン購買経験の主効果を追加したモデル， および, Model $\mathrm{A}_{3}$ は, 制御焦点とオンライン購買経験の 交互効果を追加したモデルである。自由度調整済 $\mathrm{R}^{2}$ 值 は, Model $\mathrm{A}_{1}$ に比して, Model $\mathrm{A}_{2}$ の方が有意に高く $\left(\Delta \mathrm{R}^{2}=0.22, p<0.01\right)$, Model $\mathrm{A}_{2}$ に比して Model $\mathrm{A}_{3}$ の方 が有意に高かった $\left(\Delta \mathrm{R}^{2}=0.02, p<0.05\right)$ 。したがって，制 御焦点とオンライン購買経験の主効果, および, 両者の 交互効果は，モデル全体の説明力を高めることに貢献し ていると結論づけられるだろう。

Model $\mathrm{A}_{3}$ に着目すると, 促進焦点とオンライン購買経 験の交差項の係数は, 正かつ有意であった（ $\beta_{4}=0.12$, $p<0.05)$ 。交互効果の下位検定として, オンライン購買

\begin{tabular}{|c|c|c|c|c|c|c|}
\hline 係数：説明変数 & \multicolumn{2}{|c|}{ Model $\mathrm{A}_{1}$} & \multicolumn{2}{|c|}{ Model $\mathrm{A}_{2}$} & \multicolumn{2}{|c|}{ Model $\mathrm{A}_{3}$} \\
\hline$\beta_{1}$ : 促進焦点 & & & 0.09 & $(1.57)$ & 0.08 & $(1.30)$ \\
\hline$\beta_{2}$ : 予防焦点 & & & $-0.14^{* *}$ & $(2.46)$ & $-0.16^{* * *}$ & $(2.78)$ \\
\hline$\beta_{3}:$ :ンライン購買経験 & & & $0.46^{* * *}$ & $(7.64)$ & $0.45^{* * *}$ & $(7.54)$ \\
\hline$\beta_{4}$ : 促進焦点×オンライン購買経験 & & & & & $0.12^{* *}$ & $(2.17)$ \\
\hline$\beta_{5}$ : 予防焦点 $\times$ オンライン購買経験 & & & & & -0.08 & $(1.49)$ \\
\hline$\beta_{6}:$ 実店舗までの距離 & $-0.12^{*}$ & $(1.90)$ & -0.06 & $(1.09)$ & -0.06 & $(1.11)$ \\
\hline$\beta_{7}$ : 時問制限 & 0.04 & $(0.68)$ & 0.04 & $(0.75)$ & 0.04 & $(0.78)$ \\
\hline$\beta_{8}:$ 女性ダミー & -0.03 & $(0.49)$ & $-0.16^{* * *}$ & $(2.65)$ & $-0.15^{* *}$ & $(2.58)$ \\
\hline$\beta_{0}$ : 定数項 & 0.00 & $(0.00)$ & 0.00 & $(0.00)$ & -0.01 & $(0.15)$ \\
\hline F值 & \multicolumn{2}{|c|}{1.41} & \multicolumn{2}{|c|}{12.56} & \multicolumn{2}{|c|}{10.50} \\
\hline 自由度調整済 $\mathrm{R}^{2}$ 值 & \multicolumn{2}{|c|}{0.01} & \multicolumn{2}{|c|}{0.23} & \multicolumn{2}{|c|}{0.25} \\
\hline
\end{tabular}

ただし，各セルの左側には標準化係数を，右側（括弧内）には $\mathrm{t}$ 值を示している。 $* * * p<0.01, * * p<0.05, * p<0.10$ (両側検定)。 


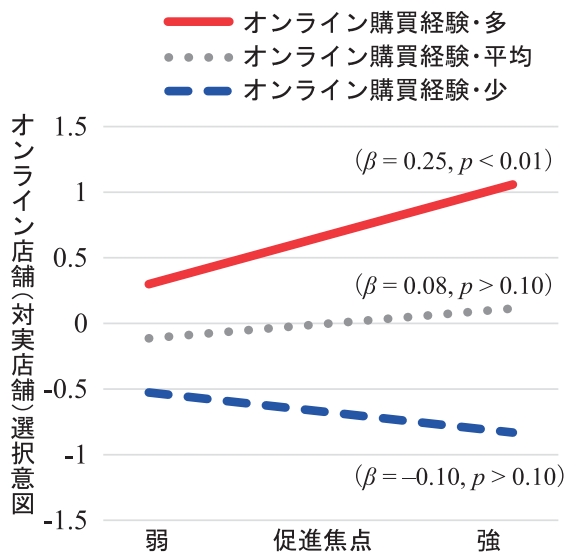

経験の多萓（平均值 $\pm 1.5 \times$ 標準偏差）における促進焦点 の単純主効果を検定した。その結果, 図 2 の左側のグラ フが描かれて，オンライン購買経験が多い場合，促進焦 点の係数は, 正かつ有意であった $(\beta=0.25, p<0.01)$ 。し たがって，仮説 1a は支持されたと結論づけられる。他 方，オンライン購買経験が少ない場合，促進焦点の係数 の符号は負であったものの，非有意であった（ $\beta=-0.10$, $p>0.10)$ 。したがって，仮説 $2 \mathrm{a}$ は支持されなかったと結 論づけられる。

また, Model $\mathrm{A}_{3}$ における予防焦点の係数は, 負かつ有 意であった $\left(\beta_{2}=-0.16, p<0.01\right)$ 。したがって，仮説 $3 \mathrm{a}$ は 支持されたと結論づけられる。他方, 予防焦点とオンラ イン購買経験の交差項の係数は, 非有意であった $\left(\beta_{5}=\right.$ $-0.08, p>0.10)$ 。したがって，仮説 $4 \mathrm{a}$ は支持されなかっ たと結論づけられる。なお, 統制変数の影響については, 女性ダミーの係数は，負かつ有意であった（ $\beta_{8}=-0.15$,

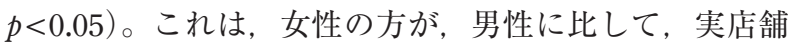
での購買を行う傾向にあるということを示唆している。

\section{2. 店舗推奨に関する分析結果}

仮説 $\mathrm{b}$ 群，すなわち，店舗推奨に関する仮説 $1 \mathrm{~b}$ 仮説 4b をテストするために, オンライン店舗(対実店舗)推奨 意図を従属変数に設定した回帰分析を行った。分析の結 果は，表 3 に示されるとおりであった。Model $\mathrm{B}_{1}$ は，統 制変数のみを組み込んだモデル，Model $\mathrm{B}_{2}$ は，制御焦点

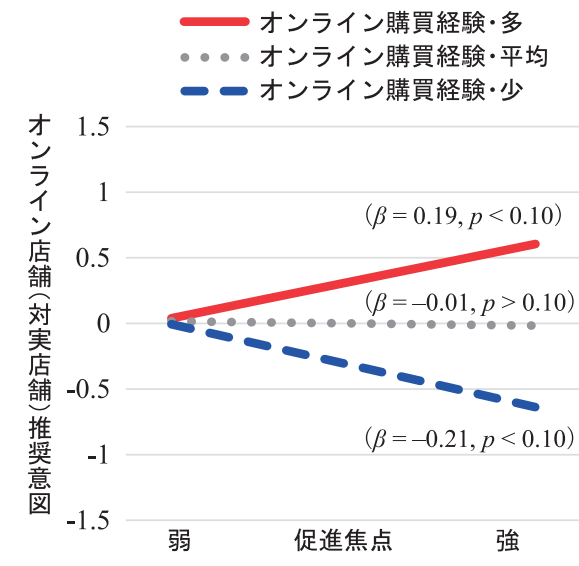

およびオンライン購買経験の主効果を追加したモデル， および, Model $\mathrm{B}_{3}$ は, 制御焦点とオンライン購買経験の 交互効果を追加したモデルである。自由度調整済 $\mathrm{R}^{2}$ 值 は, Model $\mathrm{B}_{1}$ に比して, Model $\mathrm{B}_{2}$ の方が有意に高く $\left(\Delta \mathrm{R}^{2}=0.06, p<0.01\right)$, Model $\mathrm{B}_{2}$ に比して Model $\mathrm{B}_{3}$ の方が 有意に高かった $\left(\Delta \mathrm{R}^{2}=0.01, p<0.10\right)$ 。したがって，制御 焦点とオンライン購買経験の主効果, および, 両者の交 互効果は, モデル全体の説明力を高めることに貢献して いると結論づけられるだろう。

Model $\mathrm{B}_{3}$ に着目すると, 促進焦点とオンライン購買経 験の交差項の係数は, 正かつ有意であった（ $\beta_{4}=0.13$, $p<0.05)$ 。交互効果の下位検定として, オンライン購買 経験の多寡（平均值 $\pm 1.5 \times$ 標準偏差）における促進焦点 の単純主効果を検定した。その結果, 先掲の図 2 の右側 のグラフが描かれて, オンライン購買経験が多い場合, 促進焦点の係数は, 正かつ有意であった（ $\beta=0.19$, $p<0.10)$ 。したがって, 仮説 $1 \mathrm{~b}$ は支持されたと結論づけ られる。また, オンライン購買経験が少ない場合, 促進 焦点の係数は, 負かつ有意であった $(\beta=-0.21, p<0.10)$ 。 したがって，仮説 $2 \mathrm{~b}$ も支持されたと結論づけられる。

また, Model $\mathrm{B}_{3}$ における予防焦点の係数は, 負かつ有 意であった $\left(\beta_{2}=-0.14, p<0.05\right)$ 。したがって，仮説 $3 \mathrm{~b}$ は支持されたと結論づけられる。他方，予防焦点とオン ライン購買経験の交差項の係数は, 非有意であった $\left(\beta_{5}=-0.08, p>0.10\right)$ 。したがって，仮説 $4 \mathrm{~b}$ は支持されな 


\begin{tabular}{|c|c|c|c|c|c|c|}
\hline 係数：説明変数 & \multicolumn{2}{|c|}{ Model $\mathrm{B}_{1}$} & \multicolumn{2}{|c|}{ Model $\mathrm{B}_{2}$} & \multicolumn{2}{|c|}{ Model $\mathrm{B}_{3}$} \\
\hline$\beta_{1}$ : 促進焦点 & & & 0.01 & $(0.13)$ & -0.01 & $(0.17)$ \\
\hline$\beta_{2}$ : 予防焦点 & & & $-0.12^{*}$ & $(1.89)$ & $-0.14^{* *}$ & $(2.11)$ \\
\hline$\beta_{3}$ : オンライン購買経験 & & & $0.22^{* * *}$ & $(3.34)$ & $0.21^{* * *}$ & $(3.24)$ \\
\hline$\beta_{4}$ : 促進焦点 $\times$ オンライン購買経験 & & & & & $0.13^{* *}$ & $(2.21)$ \\
\hline$\beta_{5}$ : 予防焦点 $\times$ オンライン購買経験 & & & & & -0.08 & $(0.91)$ \\
\hline$\beta_{6}$ : 実店舗までの距離 & -0.07 & $(1.02)$ & -0.04 & $(0.59)$ & -0.04 & $(0.65)$ \\
\hline$\beta_{7}$ : 時間制限 & $0.11^{*}$ & $(1.67)$ & $0.11^{*}$ & $(1.72)$ & $0.11^{*}$ & $(1.79)$ \\
\hline$\beta_{8}:$ 女性ダミー & -0.11 & (1.63) & $-0.17^{* *}$ & $(2.54)$ & $-0.16^{* *}$ & $(2.47)$ \\
\hline$\beta_{0}$ : 定数項 & 0.00 & $(0.00)$ & 0.00 & $(0.00)$ & -0.01 & $(0.15)$ \\
\hline F值 & \multicolumn{2}{|c|}{2.09} & \multicolumn{2}{|c|}{3.74} & \multicolumn{2}{|c|}{3.58} \\
\hline 自由度調整済 $\mathrm{R}^{2}$ 值 & \multicolumn{2}{|c|}{0.01} & \multicolumn{2}{|c|}{0.07} & \multicolumn{2}{|c|}{0.08} \\
\hline
\end{tabular}

ただし，各セルの左側には標準化係数を，右側（括弧内）には $\mathrm{t}$ 值を示している。 $* * * p<0.01, * * p<0.05, * p<0.10$ (両側検定)。

\begin{tabular}{|c|c|c|}
\hline 仮説 1a & $\begin{array}{l}\text { オンライン購買経験が多い場合, 促進焦点は, オンライン店舗(対実店舗)の } \\
\text { 選択に正の影響を及ぼす。 }\end{array}$ & 支持 \\
\hline 仮説 $2 \mathrm{a}$ & $\begin{array}{l}\text { オンライン購買経験が少ない場合，促進焦点は，オンライン店舗 (対実店舗) } \\
\text { の選択に負の影響を及ぼす。 }\end{array}$ & 不支持 \\
\hline 仮説 & 予防焦点は, オンライン店舗(対実店舗)の選択に負の影響を及ぼす。 & 支持 \\
\hline 仮説 4 & $\begin{array}{l}\text { オンライン購買経験は，予防焦点がオンライン店舗(対実店舗)の選択に及ぼ } \\
\text { す負の影響を抑制する。 }\end{array}$ & 不支持 \\
\hline 仮説 $1 \mathrm{~b}$ & $\begin{array}{l}\text { オンライン購買経験が多い場合, 促進焦点は, オンライン店舗(対実店舗)の } \\
\text { 選択に正の影響を及ぼす。 }\end{array}$ & 支持 \\
\hline 仮訪 & $\begin{array}{l}\text { オンライン購買経験が少ない場合，予防焦点は, オンライン店舗 (対実店舗) } \\
\text { の選択に負の影響を及ぼす。 }\end{array}$ & 支 \\
\hline 仮説 $3 \mathrm{~b}$ & 子防焦点は，オンライン店舗(対実店舗)の選択に負の影響を及ぼす。 & 支持 \\
\hline 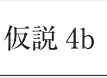 & $\begin{array}{l}\text { オンライン購買経験は，予防焦点がオンライン店舗(対実店舗)の選択に及ぼ } \\
\text { す負の影響を抑制する。 }\end{array}$ & 不了 \\
\hline
\end{tabular}

かったと結論づけられる。なお, 統制変数の影響につい ては，時間制限の係数は，正かつ有意であった $\left(\beta_{7}=0.11\right.$, $p<0.10)$ 。これは, 目的までの時間的猶予が無い時には, オンライン店舗についての推奨を行う傾向にあるという ことを示唆している。また，女性ダミーの係数は，負か つ有意であった $\left(\beta_{8}=-0.16, p<0.05\right)$ 。これは, 女性の方 が, 男性に比して, 実店舗についての推奨を行う傾向に あるということを示唆している。

\section{3. 考察}

仮説の支持・不支持に関する検討結果は，表 4 に要約
されるとおりであった。分析の結果, まず, 仮説 1 群は 支持された。すなわち, オンライン購買経験が多く, 制 御焦点が促進焦点である消費者は, オンライン店舗を選 択かつ推奨しょうとする意図が高いということが示唆さ れた。彼らは, 実店舗よりオンライン店舗で購買する快 楽感を高く知覚するため, オンライン店舗を選択すると 考えられる。さらに, オンライン店舗を選択しょうとす るだけではなく，他の消費者に対して当該店舗の利用を 勧めようとすると結論づけられる。

次に, 仮説 2 群は部分的に支持された。オンライン購 買経験が少ない場合, 促進焦点が実店舗の選択に正の影 
響を及ぼすという仮説 $2 \mathrm{a}$ は支持されなかったものの, 先 揭の図 2 に示されているように, オンライン購買経験が 少なく, 制御焦点が促進焦点である消費者は，オンライ ン店舗より実店舗で購買を行掞うとする傾向が見られた。 他方，オンライン購買経験が少ない場合，促進焦点が実 店舗の推奨に正の影響を及ぼすという仮説 $2 \mathrm{~b}$ は支持され た。オンライン購買経験が少なく, 制御焦点が促進焦点 である消費者は，オンライン店舗より実店舗で購買する 快楽感を高く知覚するため, 他の消費者に対して実店舖 の利用を勧めようとすると考えられる。

さらに，仮説 3 群は支持された一方，仮説 4 群は支持 されなかった。すなわち, オンライン購買経験の多㚖と は関係なく, 予防焦点の消費者は, 実店舖を選択・推奨し ようとする意図が高いということが示唆された。彼らは, 過去のオンライン購買経験にかかわらず，一様にオンラ イン店舗での購買に対するリスクを高く知覚するため, 実店舗を選択すると考えられる。そして，実店舗を選択 しょうとする消費者は，他の消費者に対しても実店舗の 利用を勧めようとすると結論づけられる。

\section{VI. おわりに}

\section{1. 学術的示唆}

本論は, 次の 4 点において, 消費者のチャネル選択に 関する研究，クチコミに関する研究，および，制御焦点 理論に関する研究の進展に一定の貢献を成したと言いう るだろう。第一に，本論は，消費者の制御焦点がチャネ 儿選択の規定要因となりうるということを示すことに成 功した。確かに，Kushwaha and Shankar（2013）は，消 費者の制御焦点がチャネル選択の規定要因であると主張 したものの, 彼らは, 購買店舗の種類と購買カテゴリー 間の適合性を議論する上で制御焦点に着目しただけであ り，制御焦点がチャネル選択に及ぼす影響については， 仮説として明文化しなかったし，経験的なテストも行わ なかった。本論は，制御焦点がチャネル選択に及ぼす影 響に焦点を合わせて, 仮説の導出と経験的なテストを行っ た結果，予防焦点の消費者は，オンライン店舗ではなく 実店舗を選択するという知見を提示した。この点におい
て, 消費者のチャネル選択に関する研究の進展に貢献し たと言いうるだろう。

第二に，本論は，オンライン購買経験が促進焦点の効 果を調整するということを示すことに成功した。すなわ ち, オンライン購買経験が多い場合, 促進焦点の消費者 は，実店舗ではなくオンライン店舗を選択するというこ とを見出した。これは，促進焦点の消費者は，より大き な快楽感を得られる店舗を選択するということ，そして， オンライン購買経験が多ければ, オンライン店舗での購 買によって大きな快楽感を得ることを期待するというこ とを示唆している。店舖選択に対して大きな影響を及ほ すと指摘されている快楽感に着目して, 促進焦点の消費 者の店舗選択行動を検討した点, および，オンライン購 買経験によって店舗に対する知覚快楽感が異なるという ことを示唆した点においても, 消費者のチャネル選択に 関する研究の進展に貢献したと言いうるだろう。

第三に，本論は，制御焦点がマルチ・チャネルショッ パーによるオンライン店舗(対実店舗)の選択行動のみな らず，推奨行動にも影響を及ぼすということを示すこと に成功した。制御焦点が店舗推奨行動に及ぼす影響は, シングル・チャネルの文脈に打いて探究されてきたものの (Das, 2016)，マルチ・チャネルの文脈に扔いては探究さ れてこなかった。その点, 本論は, 予防焦点が寒店舖推 奨意図に直接的に正の影響を及ぼすということ，および， 促進焦点が店舗推奨意図に及ぼす影響がオンライン購買 経験によって調整されるということを見出した。制御焦 点とマルチ・チャネルショッパーの推奨行動に関する新た な知見を提示したという点に扔いて，本論は，クチコミ 研究の進展に貢献したと言いうるだろう。

第四に，本論は，制御焦点理論が，消費者の買物行動 を探究する上で有用であるということを示すことに成功 した。1997年に Higgins によって提唱された制御焦点理 論は, 近年, マーケティング研究および消費者行動研究 において盛んに援用されているものの，その領域は主と して，広告やセールスプロモーションのような，マーケ ティング・コミュニケーションの研究分野であり, 小売や 買物行動の研究分野において, 制御焦点理論を援用した 研究はそれほど多くない。したがって, 既存研究は, 制 御焦点と消費者の買物行動の関係を探究する必要性を主 
張してきた（Arnold \& Reynolds, 2009; Das, 2016）。本論 は, こうした研究要請に応じて, 制御焦点と店舖選択・ 推奨の関係を探究したという点において, 制御焦点理論 に関する研究の進展に貢献したと言いうるだろう。

\section{2. 実務的示唆}

本論は, 実店舗とオンライン店舗の両方を有している, すなわちマルチ・チャネル戦略を採用している小売業者に 対して, 次のような実務的含意を提供しうる。本論の仮 説 1 群および仮説 2 群に関する分析の結果, オンライン 購買経験が多く, 制御焦点が促進焦点である消費者は, オンライン店舗を選択かつ推奨しようとする意図が高い ということが示された。これは，第一に，促進焦点の消 費者は買物過程で得られる快楽感を重視しているという ことを示唆している。したがって，小売業者は，促進焦 点の消費者が, 店舗で購買する快楽感を高く感じられる ように店舗設計・運営を行う必要があろう。快楽感を高 く知覚してもらうための具体的な方法として, オンライ ン店舗のサイトデザインの視覚的魅力を高めたり，ポジ ティブな感情を喚起するような BGM を活用したりする ことが考えられる (cf. Baker, Parasuraman, Grewal, \& Voss, 2002; Turley \& Milliman, 2000)。第二に, 本論の分析結果 は，消費者は，オンライン購買経験が多ければ，オンラ イン店舗での購買によって大きな快楽感を得られると知 覚するということを示唆している。したがって, オンラ イン店舖により注力する小売業者は, 消費者のオンライ ン購買経験を増やすべく、オンライン購買が増えると割 引を行うなどのプロモーションを行う一方，実店舗によ り注力する小売業者は, オンライン購買経験を増やさな いよう，実店舗での購買頻度に応じたプロモーションを 行う必要があろう。以上のような施策によって, 店舗で の購買によって大きな快楽感を得ることを期待して, 各 店舗を選択しょうとする促進焦点の消費者は, 当該店舗 を利用することを他者に積極的に推奨すると考えられる。 小売業者は, 顧客が自社の店舗を他者に勧めるような肯 定的なクチコミを発信してくれるのを歓迎すべきである。 なぜなら，肯定的なクチコミは，消費者間の当該店舗に 対する評価を高め, 既存顧客の再訪や新規顧客の訪問と いう好ましい䚻結をもたらすからである。
加えて, 本論の仮説 3 群に関する分析の結果, 予防焦 点の消費者は, 実店舗を選択かつ推奨しょうとする意図 が高いということが示された。これは, 彼らが, 購買に 伴うリスクに注目しており, から, オンライン店舗では なく実店舗で購買するリスクを低く知覚しているという ことを示唆している。したがって, 小売業者は, 彼らが, 店舗で購買するリスクを低く感じられるように店舗設計・ 運営を行う必要があ万う。彼らにリスクを低く知覚して もらうための具体的な方法として, 接客員が製品情報や 使用方法などを丁寧に説明して, 消費者の製品選択を綿 密にサポートしたり, 返品や保証, 修理サービスの情報 を的確に訴求したり，製品を実際に触って試用できるよ うにサンプルを店頭に配置したりすることが挙げられる (cf. Dai et al., 2014)。特に，オンライン店舗により注力す る小売業者は, オンライン店舖で購買するリスクを,で きる限り低く知覚してもらうために, 上述したような施 策を行うことが重要だろう。そして，こうした施策によっ て，予防焦点の消費者に，店舗で購買するリスクを感じ ることなく製品を購買させることができれば，その店舗 の利用を他者に推奨すると期待しうるだろう。

\section{3. 限界と課題}

本論は, 次の 2 点に扔いて限界を有しており, それゆ え, 今後の研究に課題を残している。第一に, 本論は, 状況要因を統制するために，仮想の購買状況に関する調 查を行った。しかしながら, 実際の購買経験に関する調 查を行えば, 店舗属性に関する知覚水準のデー夕を収集 することができる。したがって, 今後の研究には, 実際 の購買経験に関する調査を行って消費者デー夕を収集し， オンライン購買経験, 店舗に関する知覚属性水準, およ び, 制御焦点の構造的な関係を経験的に検討することが 望まれるだろう。

第二に, 本論は, オンライン購買経験が, オンライン 店舗で購買する快楽感に正の影響を与えるということを 想定して仮説を提唱した。既存研究によると，オンライ ン購買経験が多いと，ネットショッピングを行うスキル が向上し，快適に購買することができるようになり，そ れゆえ, オンライン店舗で購買する快楽感を高く知覚す るようになるという（Yang, 2012）。しかしながら，オン 
ライン購買経験が多くなったとしても，必ずしも，快楽 感を高く知覚しない消費者も存在すると考えられる。今 後の研究には，両者の因果関係を入念に検討することが 望まれるだろう。

第三に, 本論は, 調査対象財として, 単一の製品カテ ゴリー，具体的にはアパレル商品を用いた。アパレル商 品は, 快楽財かつ非規格品に分類される財である。今後 の研究には, パソコンやデジタルカメラのような実用財 や， CD や本などの規格品を対象として，消費者デー夕 を収集し，分析を行うことが望まれるだろう。

\section{謝辞}

拙稿の刊行に際して, 慶應義塾大学の小野晃典先生に 心からの謝意を表したい。拙稿の投稿をお勧めくださっ ただけでなく，投稿に至るまでに多くの貴重なご助言を 頂戴した。なお, 拙稿は, 2017 Korean Scholars of Marketing Science International Conference にて報告した Ishii, R., and Kikumori, M. (2017, November). Which Do Multichannel Shoppers Choose and Recommend: Online or Offline Stores? (Best Conference Paper Award) に基づき, 改訂を重ねて執筆されたものである。また，本研究は， JSPS 科研費 JP17J03156，および，JP18K12883 の助成を 受けた研究成果の一部である。

\section{References}

Anderson, E. (1985). The salesperson as outside agent or employee: A transaction cost analysis. Marketing Science, 4(3), 234-254.

Arnold, M. J., \& Reynolds, K. E. (2009). Affect and retail shopping behavior: Understanding the role of mood regulation and regulatory focus. Journal of Retailing, 85(3), 308-320.

Avnet, T., \& Higgins, E. T. (2006). How regulatory fit affects value in consumer choices and opinions. Journal of Marketing Research, 43(1), 1-10.

Baker, J., Parasuraman, A., Grewal, D., \& Voss, G. B. (2002). The influence of multiple store environment cues on perceived merchandise value and patronage intentions. Journal of Marketing, 66(2), 120-141.

Beatty, S. E., \& Ferrell, M. E. (1998). Impulse buying: Modelling its precursors. Journal of Retailing, 74(2), 169-191.

Bell, D. R., \& Lattin, J. M. (1998). Shopping behavior and consumer preference for store price format: Why "large basket” shoppers prefer EDLP. Marketing Science, 17(1), 6688.

Cervellon, M. C., Sylvie, J., \& Ngobo, P. V. (2015). Shopping orientations as antecedents to channel choice in the French grocery multichannel landscape. Journal of Retailing and Consumer Services, 27, 31-51.

Chocarro, R., Cortiñas, M., \& Villanueva, M. L. (2013). Situational variables in online versus offline channel choice. Electronic Commerce Research and Applications, 12(5), 347-361.

Dai, B., Forsythe, S., \& Kwon, W. S. (2014). The impact of online shopping experience on risk perceptions and online purchase intentions: Does product category matter? Journal of Electronic Commerce Research, 15(1), 13-24.

Das, G. (2016). Regulatory focus as a moderator of retail shopping behaviour. Journal of Strategic Marketing, 24(6), 484-499.

Elliot, S., \& Fowell, S. (2000). Expectations versus reality: A snapshot of consumer experiences with Internet retailing. International Journal of Information Management, 20(5), 323336.

Gehrt, K. C., \& Yan, R. N. (2004). Situational, consumer, and retailer factors affecting Internet, catalog, and store shopping. International Journal of Retail \& Distribution Management, 32(1), 5-18.

Gensler, S., Verhoef, P. C., \& Böhm, M. (2012). Understanding consumers' multichannel choices across the different stages of the buying process. Marketing Letters, 23(4), 987-1003.

Godes, D., Mayzlin, D., Chen, Y., Das, S., Dellarocas, C., Pfeiffer, B., ... \& Verlegh, P. (2005). The firm's management of social interactions. Marketing Letters, 16(3-4), 415-428.

Gorman, C. A., Meriac, J. P., Overstreet, B. L., Apodaca, S., McIntyre, A. L., Park, P., \& Godbey, J. N. (2012). A metaanalysis of the regulatory focus nomological network: Workrelated antecedents and consequences. Journal of Vocational Behavior, 80(1), 160-172.

Hahn, K. H., \& Kim, J. (2009). The effect of offline brand trust and perceived internet confidence on online shopping intention in the integrated multi-channel context. International Journal of Retail \& Distribution Management, 37(2), 126-141.

Hand, C., Dall'Olmo Riley, F., Harris, P., Singh, J., \& Rettie, R. (2009). Online grocery shopping: The influence of situational factors. European Journal of Marketing, 43(9/10), 1205-1219.

Haws, K. L., Dholakia, U. M., \& Bearden, W. O. (2010). An assessment of chronic regulatory focus measures. Journal of Marketing Research, 47(5), 967-982.

Higgins, E. T. (1997). Beyond pleasure and pain. American Psychologist, 52(12), 1280-1300.

Higgins, E. T. (1998). Promotion and prevention: Regulatory focus as a motivational principle. In P. M. Zanna (Ed.), Advances in experimental social psychology (Vol. 30, pp. 1-46). New York, NY: Academic Press.

Huang, Y., \& Oppewal, H. (2006). Why consumers hesitate to shop online: An experimental choice analysis of grocery shopping and the role of delivery fees. International Journal of Retail \& Distribution Management, 34(4/5), 334-353.

Ishii, H. (2009). The recent development of the regulatory focus theory in the consumer behavior studies. The Bulletin of the Graduate School of Commerce, 68, 147-161. (石井裕明 (2009). 「消費者行動研究に抢ける制御焦点理論研究の展開」『商学 
研究科紀要』68, 147-161）(In Japanese)

Ishii, R. (2018, February). Examining Antecedents of Dual Distribution Channels: A Resource-Based Perspective, Poster session presented at the AMA 2018 Winter Academic Conference, New Orleans, LA.

Jindal, R. P., Reinartz, W., Krafft, M., \& Hoyer, W. D. (2007). Determinants of the variety of routes to market. International Journal of Research in Marketing, 24(1), 17-29.

Kumar, V., \& Venkatesan, R. (2005). Who are the multichannel shoppers and how do they perform?: Correlates of multichannel shopping behavior. Journal of Interactive Marketing, 19(2), 44-62.

Kushwaha, T., \& Shankar, V. (2013). Are multichannel customers really more valuable? The moderating role of product category characteristics. Journal of Marketing, 77(4), 67-85.

Lockwood, P., Jordan, C. H., \& Kunda, Z. (2002). Motivation by positive or negative role models: Regulatory focus determines who will best inspire us. Journal of Personality and Social Psychology, 83(4), 854-864.

Ministry of Internal Affairs and Communications (MIC) (2017) WHITE PAPER Information and Communications in Japan, Year 2017, Retrieved June 9, 2018 from http:// www.soumu.go.jp/johotsusintokei/whitepaper/eng/WP2017/ 2017-index.html.

Monsuwé, T. P., Dellaert, B. G., \& De Ruyter, K. (2004). What drives consumers to shop online? A literature review. International Journal of Service Industry Management, 15(1), 102-121.

Montoya-Weiss, M. M., Voss, G. B., \& Grewal, D. (2003). Determinants of online channel use and overall satisfaction with a relational, multichannel service provider. Journal of the Academy of Marketing Science, 31(4), 448-458.

Neslin, S. A., Grewal, D., Leghorn, R., Shankar, V., Teerling, M. L., Thomas, J. S., \& Verhoef, P. C. (2006). Challenges and opportunities in multichannel customer management. Journal of Service Research, 9(2), 95-112.

Nicholson, M., Clarke, I., \& Blakemore, M. (2002). 'One brand, three ways to shop': Situational variables and multichannel consumer behaviour. The International Review of Retail, Distribution and Consumer Research, 12(2), 131-148.

Ono and Kikumori (2017). Effects of need-for-uniqueness on wordof-mouth sending. Japan Marketing Journal, 37(3), 22-37.（小 野晃典・菊盛真衣 (2017).「独自性欲求が口コミ発信行動 に及ぼす影響」『マーケティングジャーナル』37(3), 22-37) (In Japanese)

Oppewal, H., Timmermans, H. J., \& Louviere, J. J. (1997). Modelling the effects of shopping centre size and store variety on consumer choice behaviour. Environment and Planning $A$, 29(6), 1073-1090.

Oppewal, H., Tojib, D. R., \& Louvieris, P. (2013). Experimental analysis of consumer channel-mix use. Journal of Business Research, 66(11), 2226-2233.

Pappas, I. O., Pateli, A. G., Giannakos, M. N., \& Chrissikopoulos, V. (2014). Moderating effects of online shopping experience on customer satisfaction and repurchase intentions. International
Journal of Retail \& Distribution Management, 42(3), 187-204.

Pham, M. T., \& Higgins, E. T. (2005). Promotion and prevention in consumer decision making: The state of the art and theoretical propositions. In S. Ratneshwar \& D. G. Mick (Eds.), Inside consumption: Consumer motives, goals, and desires (pp. 8-43). London: Routledge.

Sa Vinhas, A., \& Anderson, E. (2005). How potential conflict drives channel structure: Concurrent (direct and indirect) channels. Journal of Marketing Research, 42(4), 507-515.

Summerville, A., \& Roese, N. J. (2008). Self-report measures of individual differences in regulatory focus: A cautionary note. Journal of Research in Personality, 42(1), 247-254.

Turley, L. W., \& Milliman, R. E. (2000). Atmospheric effects on shopping behavior: A review of the experimental evidence. Journal of Business Research, 49(2), 193-211.

Van Bruggen, G. H., Antia, K. D., Jap, S. D., Reinartz, W. J., \& Pallas, F. (2010). Managing marketing channel multiplicity. Journal of Service Research, 13(3), 331-340.

Verhoef, P. C., Neslin, S. A., \& Vroomen, B. (2007). Multichannel customer management: Understanding the research-shopper phenomenon. International Journal of Research in Marketing, 24(2), 129-148.

Wang, J., \& Lee, A. Y. (2006). The role of regulatory focus in preference construction. Journal of Marketing Research, 43(1), $28-38$.

Wang, Y. M., Lin, H. H., Tai, W. C., \& Fan, Y. L. (2016). Understanding multi-channel research shoppers: An analysis of Internet and physical channels. Information Systems and eBusiness Management, 14(2), 389-413.

Weiss, A. M., Anderson, E., \& MacInnis, D. J. (1999). Reputation management as a motivation for sales structure decisions. Journal of Marketing, 63(4), 74-89.

Yang, K. (2012). Consumer technology traits in determining mobile shopping adoption: An application of the extended theory of planned behavior. Journal of Retailing and Consumer Services, 19(5), 484-491.

Yu, U. J., Niehm, L. S., \& Russell, D. W. (2011). Exploring perceived channel price, quality, and value as antecedents of channel choice and usage in multichannel shopping. Journal of Marketing Channels, 18(2), 79-102.

\section{石井 隆太（いしい りゅうた）}

日本学術振興会特別研究員 (DC1)。2015 年 慶應義塾大学 商学部卒業。2017 年 慶應義塾大学大学院商学研究科修士課 程修了, 博士課程入学 (在学中), 同年より現職。専攻は, 流通論・マーケティング論。 


\section{菊盛 真衣（きくもり まい）}

立命館大学経営学部准教授。2011 年 慶應義塾大学商学部卒 業。同大学商学研究科修士課程 - 博士課程修了。博士（商 学)。東洋大学経営学部助教を経て 2017 年より現職。専攻 は，消費者行動論・マーケティング論。 